\title{
Article
}

\section{Hot-electron-assisted S-scheme heterojunction of tungsten oxide/graphitic carbon nitride for broad-spectrum photocatalytic $\mathrm{H}_{2}$ generation}

\author{
Qinqin Liu a, Xudong He ${ }^{\text {a }}$, Jinjun Peng a , Xiaohui Yu ${ }^{\text {a }}$, Hua Tang a,*, Jun Zhang b,\# \\ a School of Materials Science and Engineering Jiangsu University, Zhenjiang 212013, Jiangsu, China \\ ${ }^{\mathrm{b}}$ School of Chemical Engineering and Pharmacy, Wuhan Institute of Technology, Wuhan 430205, Hubei, China
}

\section{A R T I C L E I N F O}

\section{Article history:}

Received 23 October 2020

Accepted 19 December 2020

Available online 5 May 2021

\section{Keywords:}

Graphite carbon nitride

$\mathrm{W}_{18} \mathrm{O}_{49}$

S-scheme

Photocatalytic $\mathrm{H}_{2}$ generation

Wide spectrum

\begin{abstract}
A B S T R A C T
Extended light absorption and dynamic charge separation are vital factors that determine the effectiveness of photocatalysts. In this study, a nonmetallic plasmonic S-scheme photocatalyst was fabricated by loading $1 \mathrm{D}$ plasmonic $\mathrm{W}_{18} \mathrm{O}_{49}$ nanowires onto $2 \mathrm{D} \mathrm{g}-\mathrm{C}_{3} \mathrm{~N}_{4}$ nanosheets. $\mathrm{W}_{18} \mathrm{O}_{49}$ nanowires play the dual role of a light absorption antenna - that extends light adsorption-and a hot electron donor-that assists the water reduction reaction in a wider light spectrum range. Moreover, $\mathrm{S}$-scheme charge transfer resulting from the matching bandgaps of $\mathrm{W}_{18} \mathrm{O}_{49}$ and g- $\mathrm{C}_{3} \mathrm{~N}_{4}$ can lead to strong redox capability and high migration speed of the photoinduced charges. Consequently, in this study, $\mathrm{W}_{18} \mathrm{O}_{49} / \mathrm{g}_{-} \mathrm{C}_{3} \mathrm{~N}_{4}$ hybrids exhibited higher photocatalytic $\mathrm{H}_{2}$ generation than that of pristine g- $\mathrm{C}_{3} \mathrm{~N}_{4}$ under light irradiation of 420-550 nm. Furthermore, the $\mathrm{H}_{2}$ production rate of the best-performing $\mathrm{W}_{18} \mathrm{O}_{49} / \mathrm{g}-\mathrm{C}_{3} \mathrm{~N}_{4}$ hybrid was $41.5 \mu \mathrm{mol} \cdot \mathrm{g}^{-1} \cdot \mathrm{h}^{-1}$ upon exposure to monochromatic light at $550 \mathrm{~nm}$, whereas pure g- $\mathrm{C}_{3} \mathrm{~N}_{4}$ showed negligible activity. This study promotes novel and environmentally friendly hot-electron-assisted S-scheme photocatalysts for the broad-spectrum utilization of solar light.
\end{abstract}

(C) 2021, Dalian Institute of Chemical Physics, Chinese Academy of Sciences. Published by Elsevier B.V. All rights reserved.

\section{Introduction}

In recent years, the energy crisis has become one of the most severe concerns that threaten the human civilization. Semiconductor-based photocatalysts are promising materials that can help alleviate the global energy shortage by effectively achieving water splitting to produce clean energy [1-5]. Numerous studies have reported the development of novel high-performance semiconductor-based photocatalysts [6-8], among which layered graphite carbon nitride $\left(\mathrm{g}-\mathrm{C}_{3} \mathrm{~N}_{4}\right)$ has garnered meticulous attention owing to its appropriate band arrangement, high chemical stability, and affordable cost [9-11]. However, the low light adsorption ability of pristine g- $\mathrm{C}_{3} \mathrm{~N}_{4}$ (only responds to visible light of $\sim 420 \mathrm{~nm}$ ) and fast recombination efficacy of the photogenerated charge carriers limit its photocatalytic performance. Accordingly, extensive efforts have been devoted to addressing these issues [12,13].

Rational construction of heterostructures with plasmonic materials (noble metals or nonmetallic semiconductors) is considered an efficient way to overcome the aforementioned shortcomings because it can simultaneously widen the light-spectrum response range of photocatalysts and restrict

\footnotetext{
*Corresponding author. Tel: +86-511-88780191; E-mail: huatang79@163.com

\# Corresponding author. E-mail: zj2011@whut.edu.cn

This work was supported by the National Natural Science Foundation of China $(21975110,21972058)$ and the Taishan Youth Scholar Program of Shandong Province. 
the recombination of the charge carriers [14,15]. Plasmonic materials with unique local surface plasmon resonance (LSPR) possess distinctive photon absorption capability because they can absorb light in the visible-infrared range. Moreover, plasmon-generated hot electrons can be used as additional electron donors in photocatalytic reactions to improve photocatalytic activity [16]. The LSPR in nonmetallic semiconductor nanostructures arises from the combined vibrations of the redundant free carriers, which are associated with ion doping or lattice vacancies. Thus, the strength of LSPR can be controlled by adjusting the stoichiometric ingredients, in turn, broadening the light absorption range [17]. Among the reported plasmonic semiconductors, $\mathrm{WO}_{3-x}$ demonstrates distinct features such as innocuousness, affordability, and outstanding absorption behavior [18]. In particular, the unique nature of the outer-d valence electrons of $\mathrm{WO}_{3-x}$ confers a tailorable concentration of oxygen vacancies, rendering $\mathrm{WO}_{3-x}$ a good LSPR host for the construction of plasmon-enriched photocatalysts with extended light absorption range [19]. Furthermore, the conduction band (CB) potential of $\mathrm{g}-\mathrm{C}_{3} \mathrm{~N}_{4}(-0.91 \mathrm{~V})$ is lower than that of $\mathrm{WO}_{3-x}(0.35 \mathrm{~V})$, so that $\mathrm{g}-\mathrm{C}_{3} \mathrm{~N}_{4}$ is suitable for constructing an $\mathrm{S}$-scheme $\mathrm{WO}_{3-x} / \mathrm{g}-\mathrm{C}_{3} \mathrm{~N}_{4}$ heterojunction to preserve photoinduced charge carriers with strong redox ability [20-22]. For the $\mathrm{WO}_{3-x} / \mathrm{g}-\mathrm{C}_{3} \mathrm{~N}_{4} \mathrm{~S}$-scheme heterojunction, internal electric fields typically occur at the interface and drive the electrons in the $\mathrm{CB}$ of $\mathrm{WO}_{3-x}$ to move to the valance band (VB) of $\mathrm{g}-\mathrm{C}_{3} \mathrm{~N}_{4}$ via an S-scheme transfer process. In this design, the inefficient electrons and holes are recombined and expelled, whereas the functional electrons and holes with great redox capability are preserved [22-24]. Notably, the S-scheme simultaneously guides the movement of photogenerated carriers. Therefore, adverse charge transmission can be avoided, favoring the efficient utilization of hot electrons.

Based on the above fact, in this study, a hot electron-assisted 1D/2D $\mathrm{W}_{18} \mathrm{O}_{49} / \mathrm{g}^{-} \mathrm{C}_{3} \mathrm{~N}_{4} \mathrm{~S}$-scheme hybrid was successfully fabricated using a hydrothermal route. The photocatalytic $\mathrm{H}_{2}$-production of the $\mathrm{W}_{18} \mathrm{O}_{49} / \mathrm{g}-\mathrm{C}_{3} \mathrm{~N}_{4}$ hybrids was significantly improved than that of pristine $\mathrm{g}-\mathrm{C}_{3} \mathrm{~N}_{4}$ upon exposure to visible light. The $\mathrm{H}_{2}$ evolution rate of the hybrid, under monochromatic light irradiation of $550 \mathrm{~nm}$, reached $41.5 \mu \mathrm{mol} \cdot \mathrm{g}^{-1} \cdot \mathrm{h}^{-1}$. However, pure g- $\mathrm{C}_{3} \mathrm{~N}_{4}$ showed no activity under identical conditions. The results of X-ray photoelectron spectroscopy (XPS), photoelectrochemical tests, and electron spin resonance measurements indicated that the improvement of photocatalytic activity can be ascribed to the existence of a hot electron-assisted S-scheme that arose from the matching bandgaps of $\mathrm{W}_{18} \mathrm{O}_{49}$ and $\mathrm{g}-\mathrm{C}_{3} \mathrm{~N}_{4}$. Further, it not only accelerated the transfer of photogenerated charges but also broadened light adsorption and offered additional hot electrons for photocatalytic $\mathrm{H}_{2}$ generation over a broad spectrum of light irradiation.

\section{Experimental}

\subsection{Materials}

Urea ( $\geq 99.0 \%$ ), n-propanol ( $\geq 99.5 \%$ ), and triethanolamine $(\geq 78.0 \%$ ) were obtained from Sinopharm Chemical Reagent
Co., Ltd., while tungsten chloride ( $\left.\mathrm{WCl}_{6}, 99.9 \%\right)$ was obtained from Aladdin Industrial Corporation.

\subsection{Sample preparation}

The g- $\mathrm{C}_{3} \mathrm{~N}_{4}$ nanosheets were fabricated using a two-step calcination-thermal etching method with urea as the precursor [25]. Next, the as-prepared g- $\mathrm{C}_{3} \mathrm{~N}_{4}$ nanosheets were dispersed in $30 \mathrm{~mL}$ of hydrochloric acid and mixed for $12 \mathrm{~h}$. The obtained suspension was subsequently rinsed with deionized (DI) water to $\mathrm{pH} 7$, followed by drying at $60{ }^{\circ} \mathrm{C}$ to obtain protonated g- $\mathrm{C}_{3} \mathrm{~N}_{4}$ nanosheets ( $\mathrm{HCN}$ ). The $\mathrm{W}_{18} \mathrm{O}_{49} / \mathrm{HCN}$ composites were synthesized using a solvothermal process. Typically, $100 \mathrm{mg}$ of HCN was dispersed in $30 \mathrm{~mL}$ of $\mathrm{n}$-propanol under vigorous stirring for $30 \mathrm{~min}$. Subsequently, $50 \mathrm{mg}$ of $\mathrm{WCl}_{6}$ was mixed into the HCN suspension, and the mixture was mixed for 30 min. The obtained mixture was poured into an autoclave and maintained at $200{ }^{\circ} \mathrm{C}$ for $24 \mathrm{~h}$. The resulting sample was centrifuged, rinsed, and dehydrated at $60{ }^{\circ} \mathrm{C}$ under vacuum. Four samples were formed with the mass of HCN at 100, 150, 200, and $250 \mathrm{mg}$, and denoted as WOCN-1, WOCN-2, WOCN-3, and WOCN-4, respectively. Pure $\mathrm{W}_{18} \mathrm{O}_{49}$ was synthesized using an identical process without the addition of HCN.

\subsection{Characterization}

The crystalline phase and surface chemical status of the samples were obtained by powder X-ray diffraction (XRD) measurements using a Bruker D8 Advance (Bruker-AXS) diffractometer and XPS using a Thermo Fisher ESCALAB 250Xi instrument. The morphological features were observed via scanning electron microscopy (SEM, NovaNano 450) and transmission electron microscopy (TEM, JEOL JEM-2100). The Fourier-transform infrared (FT-IR) spectra were obtained using an infrared spectrometer (Nicolet iS50). The UV-vis diffuse reflectance spectra (DRS) were obtained on a UV-visible spectrophotometer (DRS, Shimadzu UV-2600) using $\mathrm{BaSO}_{4}$ as a standard. The transient photocurrents (TPCs), electrochemical impedance spectroscopy (EIS), and Mott-Schottky (M-S) curves were estimated using an electrochemical workstation (CHI-660E, Shanghai, China) with a three-electrode system. The steady-state and transient-state photoluminescence (PL) spectra were characterized on a QuantaMaster ${ }^{\mathrm{TM}} 40$ with an excitation of $360 \mathrm{~nm}$ incident light. The incident photon-to-current efficiency (IPCE) was tested in a three-electrode cell (platinum wire as a counter electrode and $\mathrm{Ag} / \mathrm{AgCl}$ as a reference electrode).

\subsection{Photocatalytic $\mathrm{H}_{2}$ generation test}

The photocatalytic $\mathrm{H}_{2}$-evolving experiments were performed in a Pyrex flask. For example, $25 \mathrm{mg}$ of the sample was ultrasonically disbanded in $80 \mathrm{~mL}$ of triethanolamine solution (10 vol\%), and the reactor was blown up by $\mathrm{N}_{2}$ to exhaust air. The sealed flask was illuminated with a $300 \mathrm{~W}$ xenon lamp with a $420 \mathrm{~nm}$ cut-off filter, and the amount of generated hydrogen was estimated by gas chromatography (GC-2014, Japan). The 
apparent quantum yield (AQY) was determined using the following equation:

$\mathrm{AQY}=\frac{\text { amount of released hydrogen molecules in unit time } \times 2}{\text { number of incident photons in unit time }} \times 100 \%$

\section{Results and discussion}

FT-IR spectra of the $\mathrm{HCN}, \mathrm{W}_{18} \mathrm{O}_{49}$, and $\mathrm{W}_{18} \mathrm{O}_{49} / \mathrm{HCN}$ composites were recorded and are illustrated in Fig. 1(a). The absorption bands at $3500-3000 \mathrm{~cm}^{-1}$ in the FT-IR spectrum of HCN were attributed to the surface hydroxyl and amino groups. The bands at $1650-1200 \mathrm{~cm}^{-1}$ were attributed to the stretching vibration of the heptazine units. Further, the peak at $809 \mathrm{~cm}^{-1}$ corresponded to the breathing vibration of the tri-s-triazine units $[26,27]$. The abovementioned peaks are characteristic of HCN. The characteristic absorption bands at $950-500 \mathrm{~cm}^{-1}$ in the FT-IR spectrum of pristine $\mathrm{W}_{18} \mathrm{O}_{49}$ were attributed to the stretching vibrations of the $\mathrm{O}-\mathrm{W}-\mathrm{O}$ and $\mathrm{W}=\mathrm{O}$ groups $[28,29]$. The FT-IR spectra of all $\mathrm{W}_{18} \mathrm{O}_{49} / \mathrm{HCN}$ composites were like that of pure $\mathrm{HCN}$, as it had low $\mathrm{W}_{18} \mathrm{O}_{49}$ content. However, an in-depth analysis of the FT-IR spectrum of the WOCN-3 sample revealed that the vibration peak of the s-triazine rings of $g-\mathrm{C}_{3} \mathrm{~N}_{4}$ was slightly shifted from 810.9 to $813.8 \mathrm{~cm}^{-1}$ (Fig. 1(b)), indicating that there could be a structural deformation in the "nitrogen pots" owing to the chemical interaction at the g- $\mathrm{C}_{3} \mathrm{~N}_{4} / \mathrm{W}_{18} \mathrm{O}_{49}$ interface [26,28,30]. As illustrated in Figs. $1(\mathrm{c}, \mathrm{d}), \mathrm{W}_{18} \mathrm{O}_{49}$ presented an intense diffraction peak at $23.0^{\circ}$ and three broad peaks at $26.5^{\circ}, 30.2^{\circ}$, and $44.8^{\circ}$, which could be assigned to the (010), (211), (014), and (020) crystal planes of monoclinic $\mathrm{W}_{18} \mathrm{O}_{49}$ (JCPDS No. 05-0392) [28,30]. The diffraction peaks at $13.0^{\circ}$ and $27.6^{\circ}$ in the XRD profile of HCN were attributed to the (100) and (002) diffraction planes, which correspond to the planar ordering of the tri-s-triazine units and
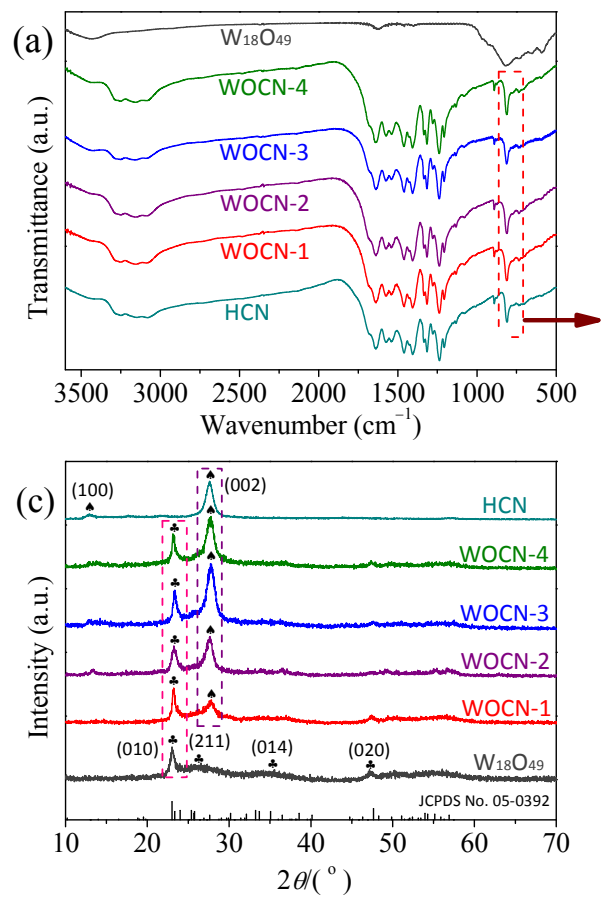

interlayer stacking, respectively [31,32]. The (002) diffraction plane of HCN shifted to a higher angle in the XRD profile of the $\mathrm{W}_{18} \mathrm{O}_{49} / \mathrm{HCN}$ composites, which implies that the internal distance between adjacent stacked $\mathrm{C}_{3} \mathrm{~N}_{4}$ sheets in the $\mathrm{W}_{18} \mathrm{O}_{49} / \mathrm{HCN}$ composite was smaller than that in HCN. Moreover, the peaks of $\mathrm{HCN}$ and $\mathrm{W}_{18} \mathrm{O}_{49}$ were found in the XRD profile of the composite samples, suggesting the successful fabrication of the $\mathrm{W}_{18} \mathrm{O}_{49} / \mathrm{HCN}$ composites.

The XPS survey profiles of the samples are presented in Fig. 2. The twin peaks at 284.7 ( $\mathrm{C}-\mathrm{C}$ bonds) and $288.0 \mathrm{eV}$ $\left(s p^{2}\right.$-hybridized carbon atoms $(\mathrm{N}-\mathrm{C}=\mathrm{N})$ ) were found in the high-resolution C 1s XPS profile of HCN (Fig. 2(a)) [33,34]. The peaks at $398.5,399.6,400.8$, and $404.4 \mathrm{eV}$ in the high-resolution N $1 s$ XPS profile of HCN (Fig. 2(b)) were assigned to the $s p^{2}$-hybridized nitrogen $(\mathrm{C}=\mathrm{N}-\mathrm{C})$, tertiary nitrogen groups $\left(\mathrm{N}-(\mathrm{C})_{3}\right)$, amino groups $(\mathrm{C}-\mathrm{N}-\mathrm{H})$, and $\mathrm{C}=\mathrm{N}$ conjugated structures, respectively $[13,35]$. The $\mathrm{W} 4 f$ high-resolution XPS profiles of $\mathrm{W}_{18} \mathrm{O}_{49}$ and $\mathrm{W}_{18} \mathrm{O}_{49} / \mathrm{HCN}$ are illustrated in Fig. 2 (c). The $\mathrm{W} 4 \mathrm{fXPS}$ profile of pure $\mathrm{W}_{18} \mathrm{O}_{49}$ can be divided into quartet peaks: the peaks at binding energies of 35.7 and 37.9 eV were ascribed to $W^{6+4} 4 f_{7 / 2}$ and $W^{6+4} f_{5 / 2}$, and the twin inadequate peaks at 34.6 and $37.1 \mathrm{eV}$ were attributed to $W^{5+4} f_{7 / 2}$ and $\mathrm{W}^{5+4} f_{5 / 2}$, respectively [36]. The $01 s$ XPS profiles of $\mathrm{W}_{18} \mathrm{O}_{49}$ and WOCN-3 presented two characteristic peaks, which corresponded to the lattice oxygen and surface-adsorbed oxygen species, respectively (Fig. 2(d)) [37]. The characteristic $01 \mathrm{~s}$ and $\mathrm{W} 4 f$ peaks of the WOCN-3 hybrid shifted by approximately $0.2 \mathrm{eV}$ toward lower binding energies compared with those of $\mathrm{W}_{18} \mathrm{O}_{49}$, and the $\mathrm{C} 1 s$ and $\mathrm{N} 1 s$ peaks of the WOCN-3 hybrid shifted toward higher binding energies, unlike the similar peaks of pure HCN. This suggested that electrons moved from $\mathrm{HCN}$ to $\mathrm{W}_{18} \mathrm{O}_{49}$ in the WOCN-3 hybrid and a built-in electric field was established at the $\mathrm{HCN} / \mathrm{W}_{18} \mathrm{O}_{49}$ interface.
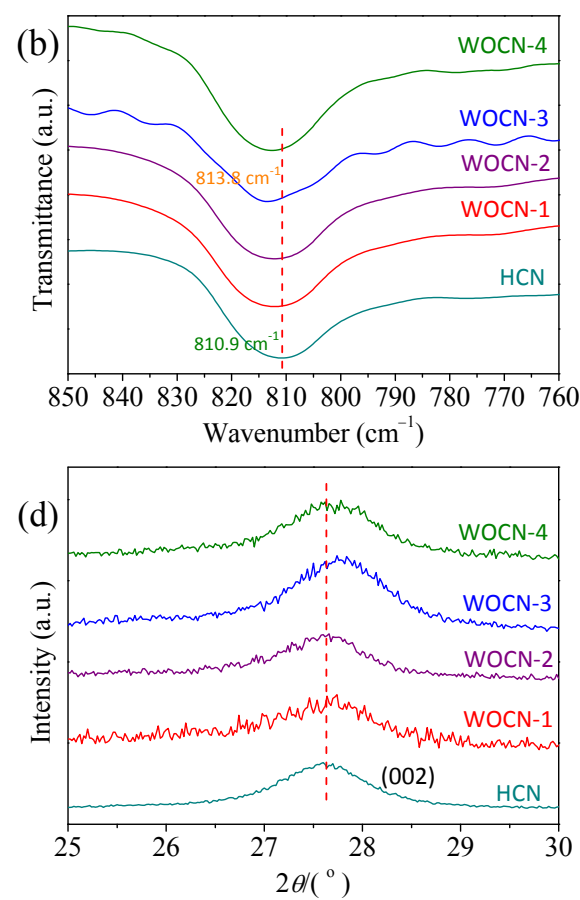

Fig. 1. FT-IR spectra (a), enlarged spectra in the range of 780-840 $\mathrm{cm}^{-1}$ (b), XRD patterns (c) and enlarged XRD patterns (d) of $\mathrm{HCN}, \mathrm{W}_{18} \mathrm{O}_{49}$, and $\mathrm{W}_{18} \mathrm{O}_{49} / \mathrm{HCN}$ composites. 

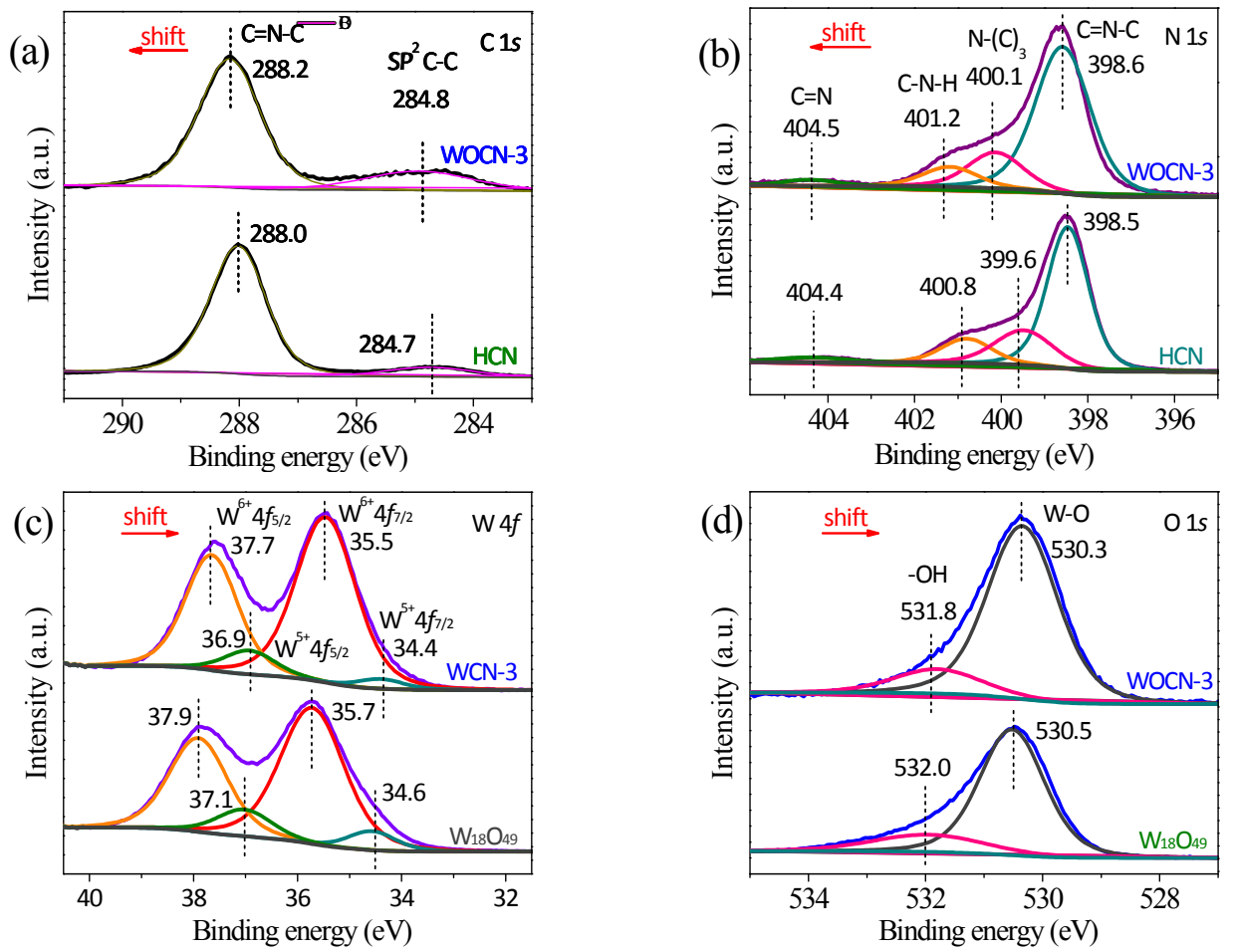

Fig. 2. High-resolution XPS spectra of C $1 s$ (a), N $1 s$ (b), W $4 f$ (c) and $01 s$ (d) of $\mathrm{HCN}, \mathrm{W}_{18} \mathrm{O}_{49}$ and WOCN-3.

Furthermore, first-principle density functional theory (DFT) calculations were performed to calculate the work functions of $\mathrm{HCN}$ and $\mathrm{W}_{18} \mathrm{O}_{49}$, which can also be utilized to analyze charge migration. The crystal information of $\mathrm{HCN}$ and $\mathrm{W}_{18} \mathrm{O}_{49}$ is listed in Table S1. The work function of HCN (3.95 eV) was lower than that of $\mathrm{W}_{18} \mathrm{O}_{49}(5.73 \mathrm{eV})$ (Figs. 3(a,b)) [25,38]. Accordingly, when $\mathrm{HCN}$ and $\mathrm{W}_{18} \mathrm{O}_{49}$ were combined to form an intimate interface, electrons would move from HCN with a small work function to $\mathrm{W}_{18} \mathrm{O}_{49}$ with a large work function until the Fermi level equilibrium was reached and a built-in electric field was formed (Figs. 3(c,d)). Moreover, the band edge of the HCN bent upward owing to the decrease in the number of electrons. However, the band edge of $\mathrm{W}_{18} \mathrm{O}_{49}$ bent downward due to the capture of electrons. These results were in good agreement with the XPS data.

The morphological features of $\mathrm{W}_{18} \mathrm{O}_{49}, \mathrm{HCN}$, and WOCN-3

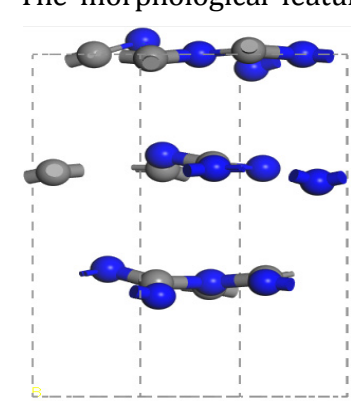

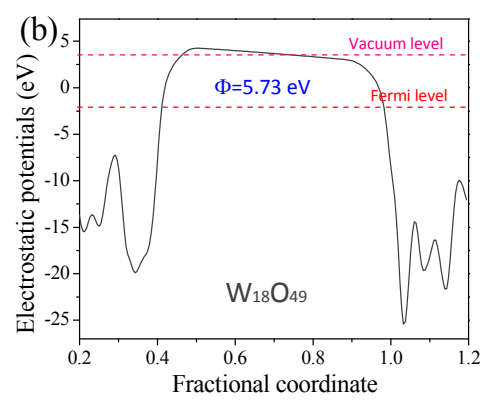

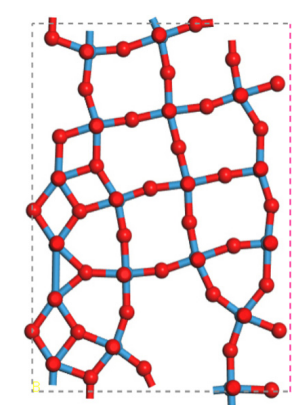

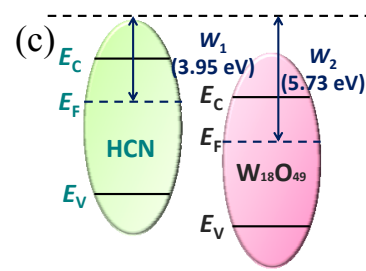

Before contact

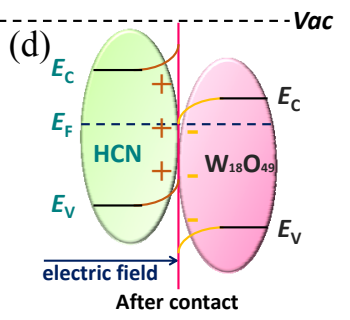

Fig. 3. Work functions of HCN (001) surface (b) and $\mathrm{W}_{18} \mathrm{O}_{49}$ (001) surface (b); the band-alignments of the $\mathrm{HCN}$ and $\mathrm{W}_{18} \mathrm{O}_{49}$ before (c) and after (d) contact. 


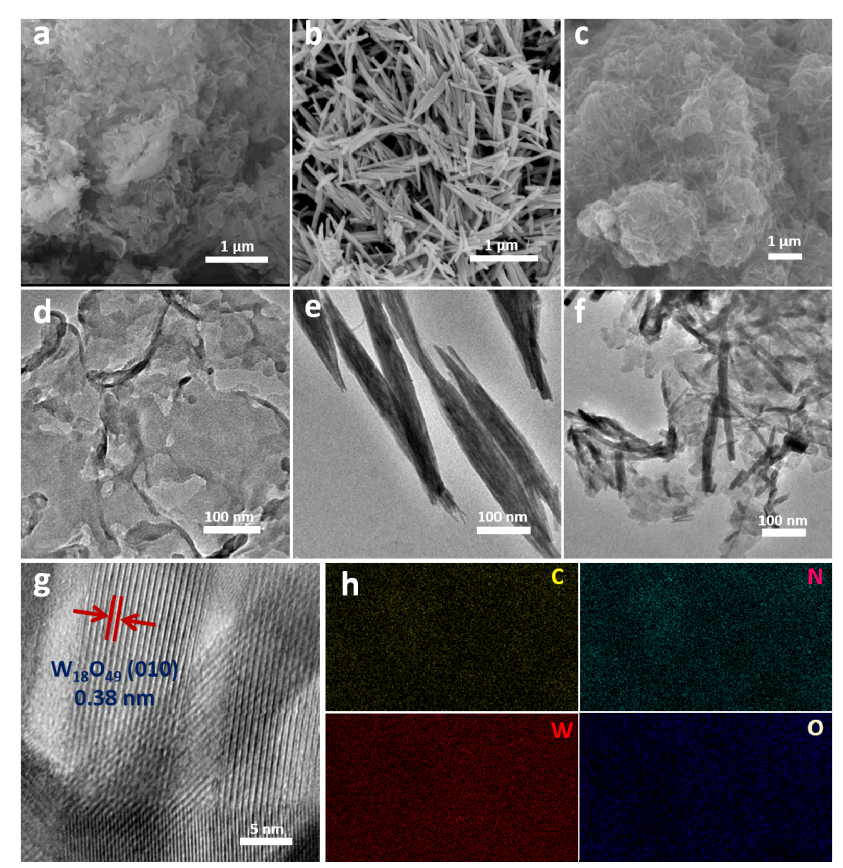

Fig. 4. SEM and TEM images of $\mathrm{HCN}(\mathrm{a}, \mathrm{d}), \mathrm{W}_{18} \mathrm{O}_{49}(\mathrm{~b}, \mathrm{e})$ and WOCN-3 (c, f); HRTEM image (g) and EDX elemental mapping (h) of WOCN-3.

were investigated, and the pristine HCN sample presented a wrinkled irregular thin-layer nanosheet structure (Figs. 4(a,b)), and the pure $\mathrm{W}_{18} \mathrm{O}_{49}$ sample presented a spindle-like nanowire morphology with lengths and widths of $\sim 800$ and $50 \mathrm{~nm}$, respectively (Figs. 4(c,d)). For the WOCN-3 sample, many spindle-like $\mathrm{W}_{18} \mathrm{O}_{49}$ nanowires were closely anchored to the surface of the lamellar HCN (Figs. 4(e,f)). The length of the spindle-like $\mathrm{W}_{18} \mathrm{O}_{49}$ nanowires in the WOCN-3 composite decreased to approximately $300 \mathrm{~nm}$, probably due to the confinement effect of the 2D HCN nanosheets, which served as growing support. An interplanar distance of $0.38 \mathrm{~nm}$, which was ascribed to the (010) lattice reflection of the monoclinic $\mathrm{W}_{18} \mathrm{O}_{49}$, was distinctly observed in the HR-TEM image of WOCN-3 (Fig. 4(g)) [39,40]. Elemental mapping analysis confirmed that $\mathrm{C}, \mathrm{N}, \mathrm{W}$, and $\mathrm{O}$ were evenly distributed throughout the WOCN-3 composite (Fig. $4(\mathrm{~h})$ ). These results further indicated that the $1 \mathrm{D} \mathrm{W} \mathrm{W}_{18} \mathrm{O}_{49}$ nanowires could be decorated on the surface of the 2D HCN to form a 1D/2D heterojunction with intimate interfacial contact. The water-wetting properties of the HCN and WOCN-3 samples were investigated, and it was found that the WOCN-3 hybrid presented a lower contact angle $\left(26.3^{\circ}\right)$ compared to that of the HCN $\left(102.1^{\circ}\right)$, indicating that the WOCN-3 hybrid yields better hydrophilic properties for water contact, which is beneficial for the water-splitting reaction.

Furthermore, Brunauer-Emmett-Teller (BET) was employed to study the specific area and pore structure of the HCN and WOCN-3. As shown in Fig. 5, both samples demonstrate the type IV choroisotherm and containing an average pore size in the range of 2-4 nm, indicating the presence of mesopores. The WOCN-3 hybrid possesses a higher BET surface area (93.98 $\left.\mathrm{m}^{2} \cdot \mathrm{g}^{-1}\right)$ and larger pore volume $\left(0.55 \mathrm{~cm}^{3} \cdot \mathrm{g}^{-1}\right)$ compared to those of the HCN (BET surface area is $73.03 \mathrm{~m}^{2} \cdot \mathrm{g}^{-1}$ and pore volume is $0.43 \mathrm{~cm}^{3} \cdot \mathrm{g}^{-1}$ ). The larger BET surface area of the WOCN-3 hybrid offers more reactive sites, which favors the photocatalytic water-splitting reaction.

The photocatalytic $\mathrm{H}_{2}$ production of $\mathrm{HCN}$ and the $\mathrm{W}_{18} \mathrm{O}_{49} / \mathrm{HCN}$ hybrids with different $\mathrm{W}_{18} \mathrm{O}_{49}$-to-HCN ratios were analyzed when these catalysts were exposed to visible light in a suspension of lactic acid as the sacrificial agent. The pristine HCN presented a relatively low $\mathrm{H}_{2}$ production activity of 259 $\mu \mathrm{mol} \cdot \mathrm{g}^{-1} \cdot \mathrm{h}^{-1}$ (Figs. $6(\mathrm{a}, \mathrm{b})$ ). The $\mathrm{H}_{2}$ generation of the $\mathrm{W}_{18} \mathrm{O}_{49} / \mathrm{HCN}$ composites was significantly higher than that of $\mathrm{HCN}$, and the WOCN-3 sample presented an optimal $\mathrm{H}_{2}$ evolution rate of $892 \mu \mathrm{mol} \cdot \mathrm{g}^{-1} \cdot \mathrm{h}^{-1}$, which was approximately 3.4 times higher than that of pure HCN. The photocatalytic activity of the WOCN-3 sample was also compared with those of the g- $\mathrm{C}_{3} \mathrm{~N}_{4}$-based photocatalysts. This activity was similar to those reported recently (Table S2). Furthermore, the stability of the WOCN-3 sample under visible light irradiation was analyzed (Fig. 7). The $\mathrm{H}_{2}$ generation of WOCN-3 did not decrease after a cycling experiment in which the reactants and photocatalyst were not refreshed, which suggested that WOCN-3 exhibited excellent stability for the photocatalytic production of $\mathrm{H}_{2}$.

The photocatalytic wavelength-dependent apparent quantum yields of WOCN-3 measured at 420,450, and $520 \mathrm{~nm}$ were $6.21 \%, 1.28 \%$, and $0.14 \%$, respectively (Fig. 8(a)). Furthermore, the photocatalytic $\mathrm{H}_{2}$ production of the $\mathrm{HCN}, \mathrm{W}_{18} \mathrm{O}_{49}$, and $\mathrm{W}_{18} \mathrm{O}_{49} / \mathrm{HCN}$ samples was investigated under $550 \mathrm{~nm}$ monochromatic light irradiation. The $\mathrm{H}_{2}$ evolution rate over WOCN-3 was still $41.5 \mu \mathrm{mol} \cdot \mathrm{g}^{-1} \cdot \mathrm{h}^{-1}$, and pure $\mathrm{HCN}$ and $\mathrm{W}_{18} \mathrm{O}_{49}$ did not generate any $\mathrm{H}_{2}$ (Fig. 8(b)). Under $550 \mathrm{~nm}$ monochromatic light irradiation, $\mathrm{HCN}$ cannot generate photoelectrons for the water reduction reaction. Consequently, the plasmonic $\mathrm{W}_{18} \mathrm{O}_{49}$ nanowires produced the hot electrons that could migrate to the $\mathrm{CB}$
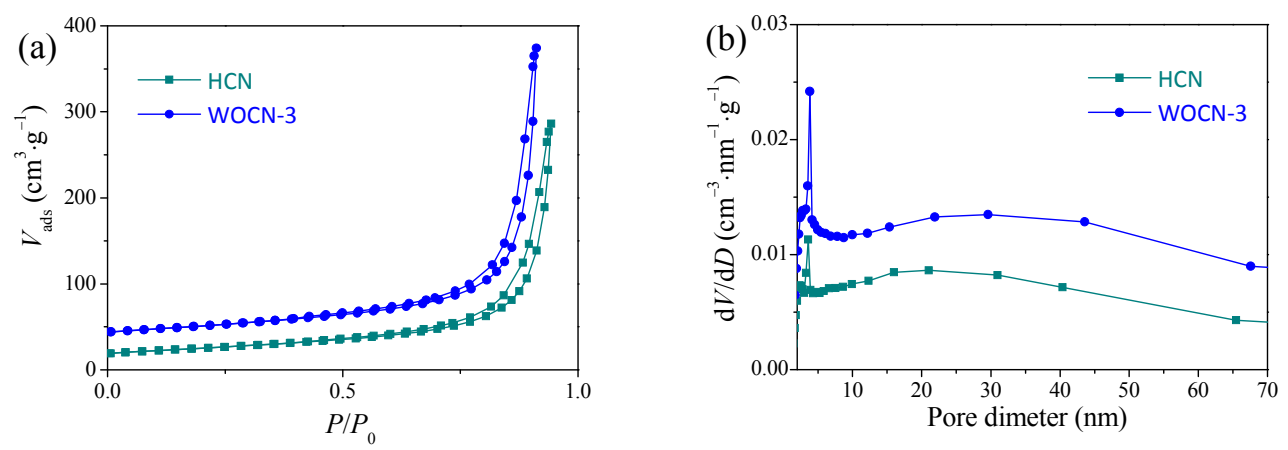

Fig. 5. $\mathrm{N}_{2}$ sorption isotherm (a) and pore size distribution (b) over HCN and WOCN-3. 

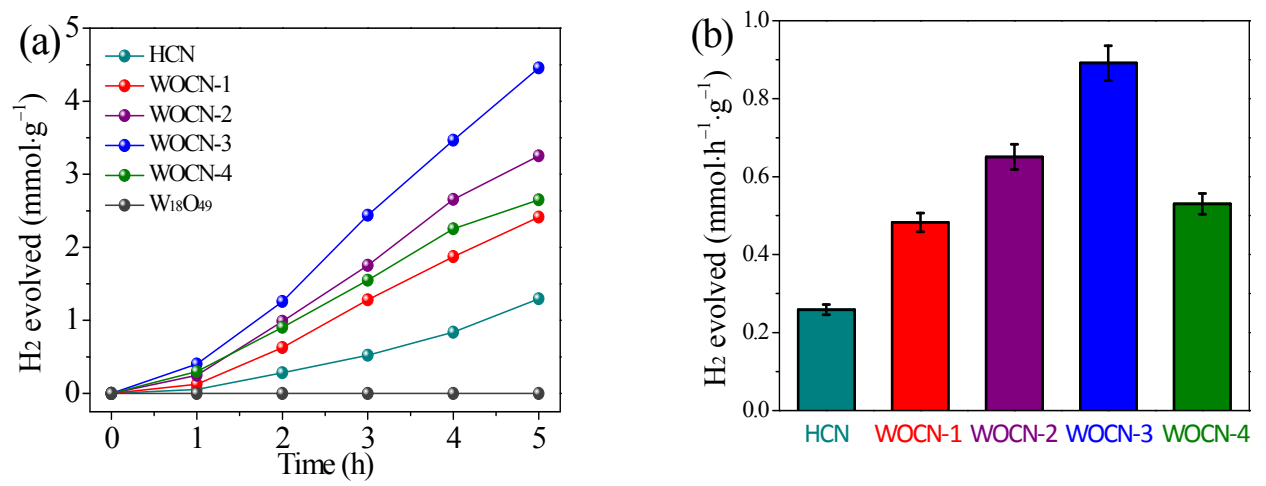

Fig. 6. Photocatalytic $\mathrm{H}_{2}$-production activities (a) and $\mathrm{H}_{2}$-production rates (b) of $\mathrm{HCN}, \mathrm{W}_{18} \mathrm{O}_{49}$, and $\mathrm{W}_{18} \mathrm{O}_{49} / \mathrm{HCN}$ samples.

band of the HCN and participate in photocatalytic $\mathrm{H}_{2}$ generation. The IPCE spectra of the HCN and WOCN-3 were measured and are presented in Fig. S2. HCN shows a low IPCE $0.048 \%$ at $450 \mathrm{~nm}$ ), and WOCN-3 exhibits enhanced IPCE compared to that of HCN, which is according to the photocatalytic activity [41]. Accordingly, the introduction of $1 \mathrm{D} \mathrm{W}_{18} \mathrm{O}_{49}$ nanowires with the LSPR effect is the vital factor that can effectively improve the photocatalytic performance of the HCN nanosheets over a broad light spectrum.

Light-harvesting capability is an essential feature that affects photocatalytic performance. The optical properties of the $\mathrm{HCN}, \mathrm{W}_{18} \mathrm{O}_{49}$, and $\mathrm{W}_{18} \mathrm{O}_{49} / \mathrm{HCN}$ composites were measured using diffuse reflectance spectroscopy. The light absorption edges of $\mathrm{HCN}$ and $\mathrm{W}_{18} \mathrm{O}_{49}$ were located at approximately 460 and $485 \mathrm{~nm}$, respectively (Fig. 9). Compared with the traditional $\mathrm{WO}_{3}$ catalyst, $\mathrm{W}_{18} \mathrm{O}_{49}$ presented a distinct tail absorption at approximately 500-1200 $\mathrm{nm}$ due to the LSPR effect that arose from the abundant oxygen vacancies of $\mathrm{W}_{18} \mathrm{O}_{49}[40,41]$. Combining the W18049 plasmon with HCN caused the maximum absorption edge of the $\mathrm{W}_{18} \mathrm{O}_{49} / \mathrm{HCN}$ heterojunction to move to a longer wavelength than that of HCN. Moreover, a wider tail absorption band appeared in the $\mathrm{W}_{18} \mathrm{O}_{49} / \mathrm{HCN}$ heterojunction owing to the $\mathrm{W}_{18} \mathrm{O}_{49}$ plasmon. This phenomenon indicates that the synergy between $\mathrm{HCN}$ and $\mathrm{W}_{18} \mathrm{O}_{49}$ can effectively enhance the light-capturing ability of the photocatalyst heterojunctions over the entire spectral range. For $\mathrm{W}_{18} \mathrm{O}_{49} / \mathrm{HCN}$, plasmonic $\mathrm{W}_{18} \mathrm{O}_{49}$ can utilize light at $550 \mathrm{~nm}$ to manufacture additional hot electrons that would transfer to the CB band of the HCN and participate in the water reduction reaction, promoting the activity of the photocatalyst over a wide spectrum [42].

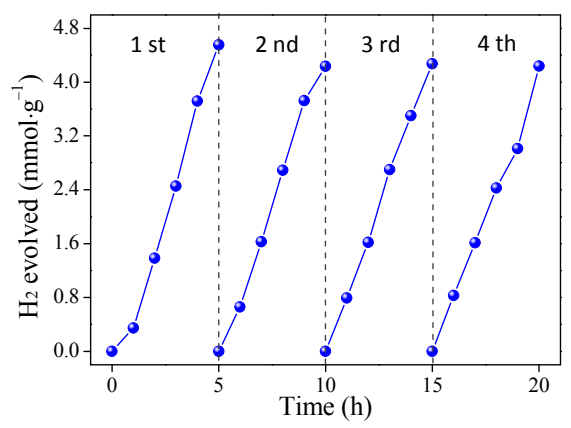

Fig. 7. Cycle stability experiments of WOCN-3.
To investigate the photoinduced charge separation and transference response of the as-prepared $\mathrm{HCN}, \mathrm{W}_{18} \mathrm{O}_{49}$, and WOCN-3 samples, their transient photocapacitance responses, EIS profiles, photoluminescence (PL) spectra, and time-resolved photoluminescence (TRPL) spectra were analyzed. The WOCN-3 sample presented the highest photocurrent density of all analyzed samples, which was approximately 2.1 and 3.5 times higher than those of $\mathrm{HCN}$ and $\mathrm{W}_{18} \mathrm{O}_{49}$, respectively, (Fig. 10(a)), indicating that WOCN-3 presented optimal detachment speed of the photogenerated electron-hole pairs [43]. The EIS profiles of the samples are shown in Fig. 10(b). The arc span of the WOCN-3 hybrid was smaller than those of $\mathrm{HCN}$ and $\mathrm{W}_{18} \mathrm{O}_{49}$, which demonstrated that WOCN-3 presented lower charge transport resistance and faster interfacial charge transfer than $\mathrm{HCN}$ and $\mathrm{W}_{18} \mathrm{O}_{49}[44,45]$. The PL emission spectra of the synthesized HCN and WOCN-3 samples are illustrated in Fig. 10(c). The PL peak intensity of the WOCN-3 hybrid at 450
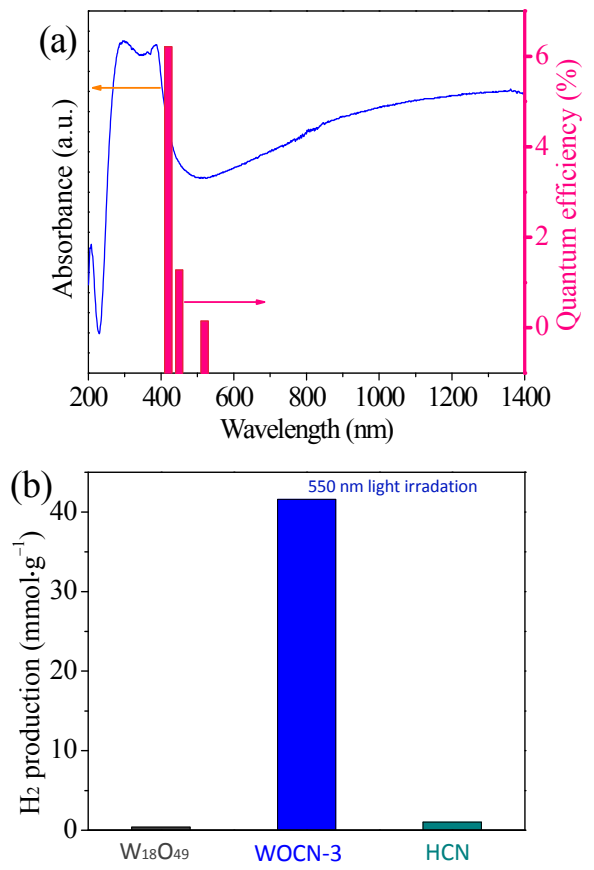

Fig. 8. (a) Wavelength-dependent AQY of WOCN-3; (b) $\mathrm{H}_{2}$-production performances of $\mathrm{HCN}, \mathrm{W}_{18} \mathrm{O}_{49}$, and WOCN-3 under $550 \mathrm{~nm}$ monochromic light irradiation. 


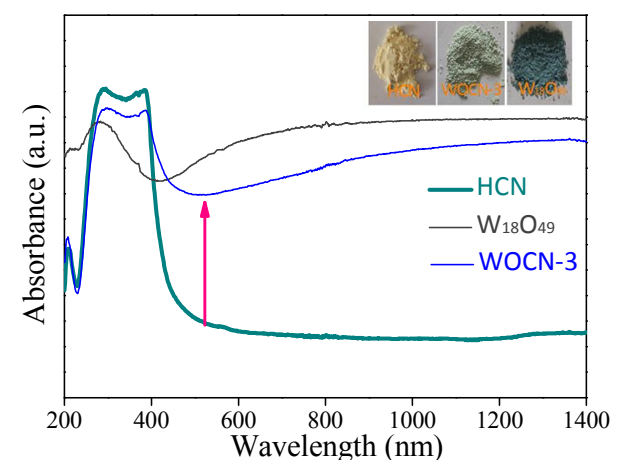

Fig. 9. UV-vis spectra of $\mathrm{HCN}, \mathrm{W}_{18} \mathrm{O}_{49}$ and the $\mathrm{W}_{18} \mathrm{O}_{49} / \mathrm{HCN}$ composites.

nm was lower than that of HCN, indicating that the recombination rate of the photogenerated carriers over the WOCN-3 hybrid was lower than that of the HCN $[46,47]$. The TRPL spectra indicated that the mean fluorescence lifetime of the WOCN-3 composite $(0.99 \mathrm{~ns})$ was lower than that of HCN (2.00 ns) (Fig. $10(d)$ ), which suggests that the WOCN-3 hybrid presented faster electron-hole detachment and transference than HCN [48-50]. These results confirmed that the construction of the $1 \mathrm{D} / 2 \mathrm{D} \mathrm{W}_{18} \mathrm{O}_{49} / \mathrm{HCN}$ heterojunction could adequately improve the detachment and migration of the photogenerated carriers, and therefore, the heterojunction presented better photocatalytic water-splitting performance than HCN.

The bandgaps of the synthesized HCN and $\mathrm{W}_{18} \mathrm{O}_{49}$ samples were determined using the Kubelka-Munk equation to be 2.68 and $2.55 \mathrm{eV}$, respectively (Fig. 11(a)). The flat-band potentials $\left(E_{\mathrm{fb}}\right)$ of $\mathrm{HCN}$ and $\mathrm{W}_{18} \mathrm{O}_{49}$ were -1.14 and $0.12 \mathrm{~V}$ (vs. $\mathrm{Ag} / \mathrm{AgCl}, \mathrm{pH}$ = 6.8), respectively, using Mott-Schottky plots (Fig. 11(b) and (c), respectively). The $E_{\mathrm{CB}}$ values were calculated to be -0.84
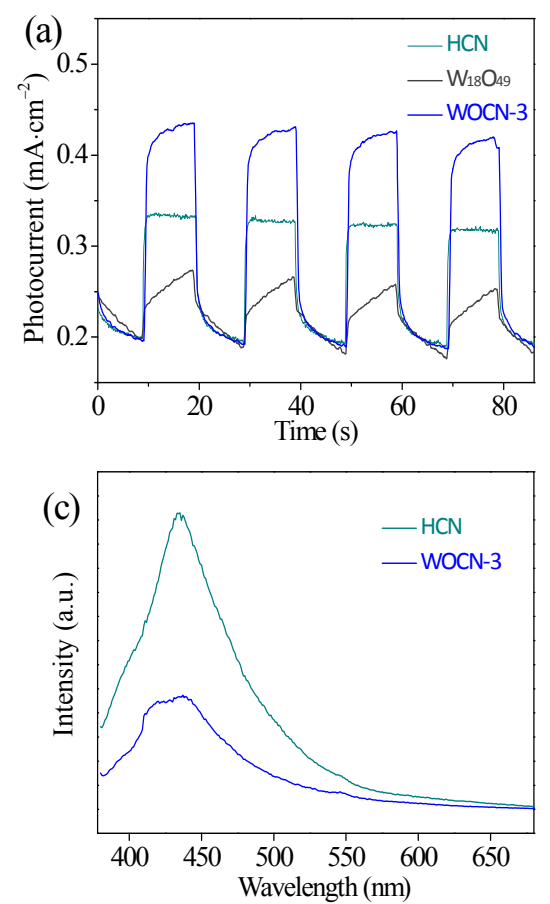

and $0.42 \mathrm{~V}$ (vs. NHE, $\mathrm{pH}=0$ ) using the equation $E_{\mathrm{fb}}=E_{\mathrm{Ag} / \mathrm{AgCl}}+$ $0.059 \times \mathrm{pH}+E^{\theta} \mathrm{Ag} / \mathrm{AgCl}\left(\mathrm{pH}=6.8\right.$ and $\left.E_{\mathrm{Ag} / \mathrm{AgCl}}=0.197 \mathrm{~V}\right)[51,52]$. The bandgap configurations and corresponding band positions of $\mathrm{HCN}$ and $\mathrm{W}_{18} \mathrm{O}_{49}$ are presented in Fig. 11(d). To gain a deeper understanding of the photocatalytic mechanism, the active free radicals produced by the $\mathrm{HCN}, \mathrm{W}_{18} \mathrm{O}_{49}$, and WOCN-3 photocatalysts were identified using electron spin resonance (ESR) experiments. The reaction of TEMPO with electrons produced an ESR-silent molecule, which caused a reduction in the intensity of the ESR signal. Consequently, the reduced intensity of the TEMPO signal indicated the production of additional electrons upon illumination [53]. The ESR signal strength of WOCN-3 was significantly weaker than those of HCN and $\mathrm{W}_{18} \mathrm{O}_{49}$ (Fig. 11(e)), which confirmed that more electrons were generated using WOCN-3 than using $\mathrm{HCN}$ or $\mathrm{W}_{18} \mathrm{O}_{49}$. Based on these results, it was concluded that the $\mathrm{W}_{18} \mathrm{O}_{49} / \mathrm{HCN}$ heterojunction could produce more active free radicals than the individual components and promote the photocatalytic reaction. DMPO, a spin trap molecule, is ESR-silent. After capturing the generated hydroxyl radicals $(\cdot \mathrm{OH})$, DMPO could react with them to form a spin adduct (DMPO--OH), presenting an ESR signal [53]. Fig. 11(f) illustrates the ESR signals of $\mathrm{HCN}, \mathrm{W}_{18} \mathrm{O}_{49}$, and WOCN-3 for the $\cdot \mathrm{OH}$ species in an aqueous solution. Both $\mathrm{W}_{18} \mathrm{O}_{49}$ and WOCN-3 presented a typical four-line pattern with a relative magnitude of 1:2:2:1. However, HCN did not present any ESR signal under light irradiation, which was ascribed to the VB position of HCN (1.84 V vs. NHE) being more negative than the redox potential of $\mathrm{H}_{2} \mathrm{O} / \cdot \mathrm{OH}(2.40 \mathrm{~V})$, indicating that HCN could not generate $\cdot \mathrm{OH}$ species $[54,55]$. The transfer of photogenerated charge carriers followed an S-scheme rather than the traditional type-II heterojunction mechanism [57].

Based on the presented results, a plasmon-enhanced S-scheme was assumed for the $\mathrm{W}_{18} \mathrm{O}_{49} / \mathrm{HCN}$ hybrid (Fig. 12).
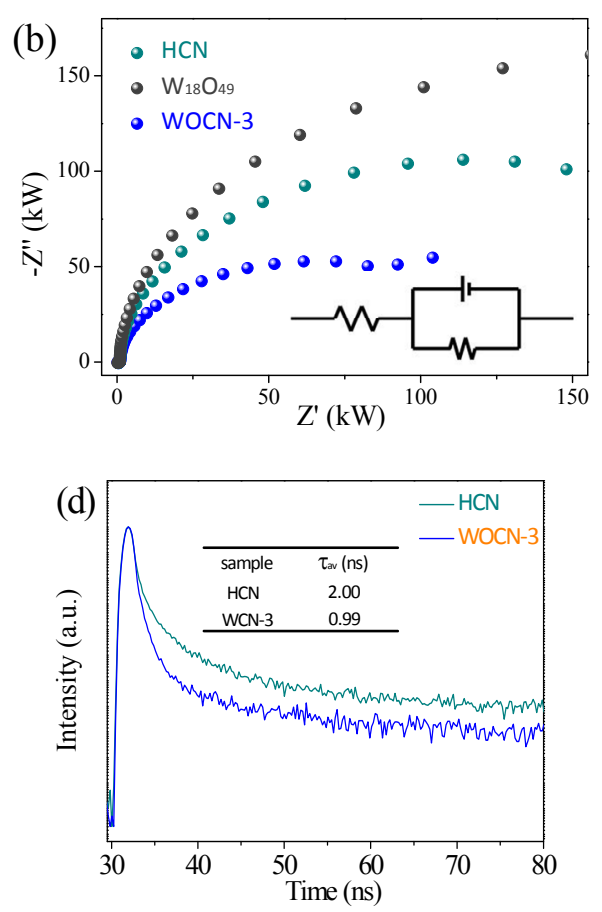

Fig. 10. Transient photocurrent responses (a) and EIS plots (b) of HCN, $\mathrm{W}_{18} \mathrm{O}_{49}$ and WOCN-3; PL (c) and TRPL (d) of HCN and WOCN-3. 

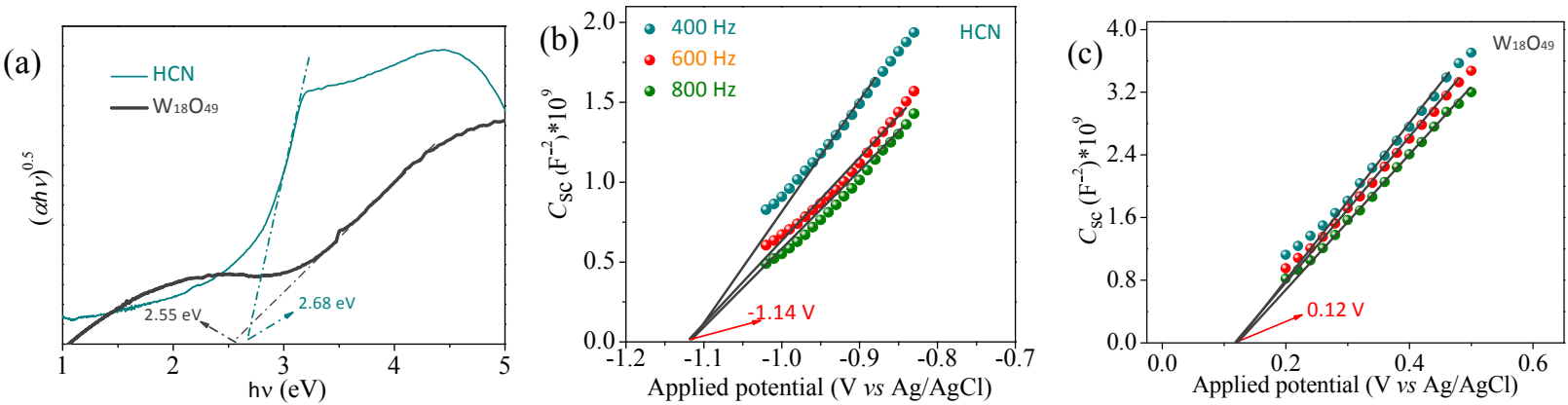

(d)

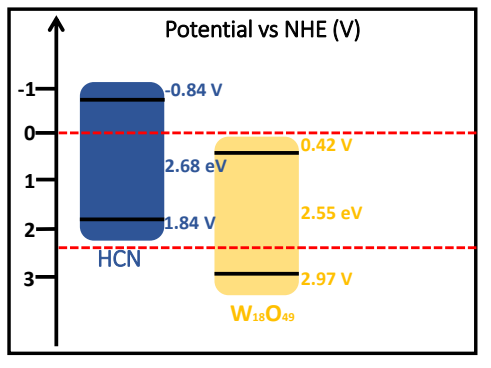

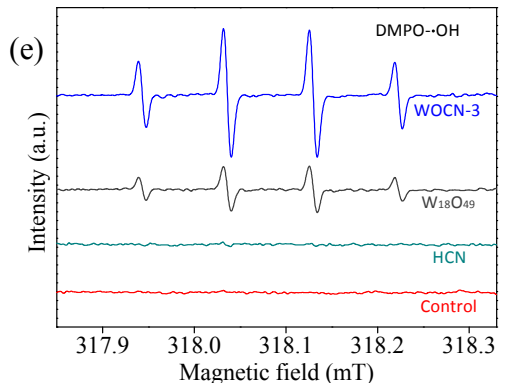

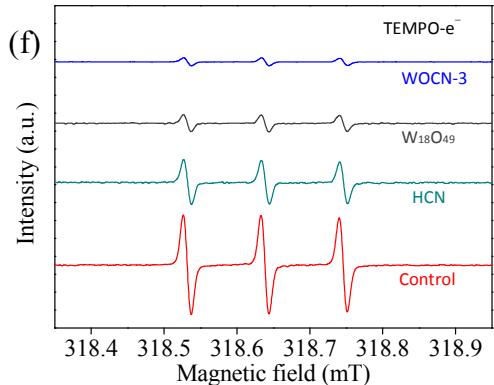

Fig. 11. Band gaps (a), Mott-Schottky plots (b,c) and band alignments (d) over $\mathrm{HCN}$ and $\mathrm{W}_{18} \mathrm{O}_{49}$; comparison of ESR spectra of DMPO-•OH (e) and TEMPO -e- (f) over $\mathrm{HCN}, \mathrm{W}_{18} \mathrm{O}_{49}$ and WOCN-3 samples.

According to the energy band position, the $\mathrm{CB}$ potential of $\mathrm{W}_{18} \mathrm{O}_{49}$ cannot meet the thermodynamic requirements of photocatalytic $\mathrm{H}_{2}$ production, and the VB position of HCN cannot generate $\bullet \mathrm{OH}$ species. However, under visible light irradiation, the photocatalytic activity and $\bullet \mathrm{OH}$ generation capacity of the $\mathrm{W}_{18} \mathrm{O}_{49} / \mathrm{HCN}$ composite was higher than those of $\mathrm{HCN}$. The charge transfer of the $\mathrm{W}_{18} \mathrm{O}_{49} / \mathrm{HCN}$ hybrid did not conform to the traditional type-II heterojunction mechanism. If the heterojunction followed a type-II charge transport mechanism after the $\mathrm{W}_{18} \mathrm{O}_{49} / \mathrm{HCN}$ hybrid was excited by light, the photogenerated electrons were transferred from $\mathrm{HCN}$ to the $\mathrm{CB}$ of $\mathrm{W}_{18} \mathrm{O}_{49}$, and the $\mathrm{CB}$ position of $\mathrm{W}_{18} \mathrm{O}_{49}$ would not meet the requirements for $\mathrm{H}_{2}$ production. In contrast, the plasmon-enhanced S-scheme heterojunction described in the introduction could explain the enhanced photocatalytic activity of the $1 \mathrm{D} / 2 \mathrm{D} \mathrm{W}_{18} \mathrm{O}_{49} / \mathrm{HCN}$ hybrid. After $\mathrm{HCN}$ and $\mathrm{W}_{18} \mathrm{O}_{49}$ were excited using visible light, they produced photogenerated electrons and holes, and the electrons in the $\mathrm{CB}$ of $\mathrm{W}_{18} \mathrm{O}_{49}$ would combine with the holes in the VB of HCN driven by the built-in electric field. Consequently, the photogenerated electrons with

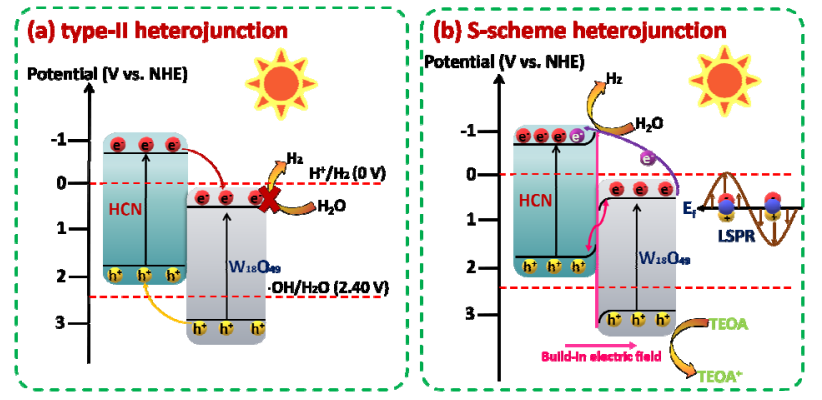

Fig. 12. Hot electron assisted S-scheme over $\mathrm{W}_{18} \mathrm{O}_{49} / \mathrm{HCN}$ hybrid for photocatalytic $\mathrm{H}_{2}$-production. strong reducing ability were retained at the CB position of HCN and participated in the water-splitting reaction. Furthermore, the $\mathrm{W}_{18} \mathrm{O}_{49}$ plasmon can generate hot electrons under $550 \mathrm{~nm}$ light irradiation, causing high photocatalytic performance over a broad spectrum.

\section{Conclusions}

In summary, a plasmonic $1 \mathrm{D} / 2 \mathrm{D} \mathrm{W}_{18} \mathrm{O}_{49} / \mathrm{HCN}$ S-scheme heterojunction photocatalyst with an extended absorption spectrum was fabricated using a hydrothermal route. The $\mathrm{W}_{18} \mathrm{O}_{49} / \mathrm{HCN}$ hybrid exhibited improved photocatalytic $\mathrm{H}_{2}$ production activity under wide-spectrum irradiation. Under $550 \mathrm{~nm}$ monochromatic light irradiation, the $\mathrm{H}_{2}$ generation rate over the $\mathrm{W}_{18} \mathrm{O}_{49} / \mathrm{g}-\mathrm{C}_{3} \mathrm{~N}_{4}$ hybrid was $41.5 \mu \mathrm{mol} \cdot \mathrm{g}^{-1} \cdot \mathrm{h}^{-1}$, whereas that over g- $\mathrm{C}_{3} \mathrm{~N}_{4}$ was negligible. Such improved photocatalytic performance was attributed to the expanded light absorption and fast charge separation resulting from the S-scheme charge transfer mechanism. Simultaneously, plasmonic $\mathrm{W}_{18} \mathrm{O}_{49}$ nanowires serving as a hot electron donor could inject hot electrons into HCN nanosheets to assist the water reduction reaction under a wider light spectrum. It is supposed that this report provides new insights for the design of subsequent hot electron-assisted S-scheme heterojunction photocatalysts.

\section{References}

[1] Q. Q. Liu, J. Y. Shen, X. F. Yang, T. R. Zhang, H. Tang, Appl. Catal. B, 2018, 232, 562-573.

[2] R. R. Gao, B. Cheng, J. J. Fan, J. G. Yu, W. K. Ho, Chin. J. Catal., 2021, $42,15-24$.

[3] R. Wang, J. Shen, K. H. Sun, H. Tang, Q. Q. Liu, Appl. Surf. Sci., 2019, 493, 1142-1149. 


\section{Graphical Abstract}

Chin. J. Catal., 2021, 42: 1478-1487 doi: 10.1016/S1872-2067(20)63753-6

Hot-electron-assisted S-scheme heterojunction of tungsten oxide/graphitic carbon nitride for broad-spectrum photocatalytic $\mathrm{H}_{2}$ generation

Qinqin Liu, Xudong He, Jinjun Peng, Xiaohui Yu, Hua Tang*, Jun Zhang*

Jiangsu University; Wuhan Institute of Technology

A plasmonic 1D/2D $\mathrm{W}_{18} \mathrm{O}_{49} / \mathrm{HCN}$ S-scheme heterojunction photocatalyst was synthesized, and $\mathrm{W}_{18} \mathrm{O}_{49}$ plasmon can generate hot electrons that helped to achieve high photocatalytic performance over a broad spectrum.

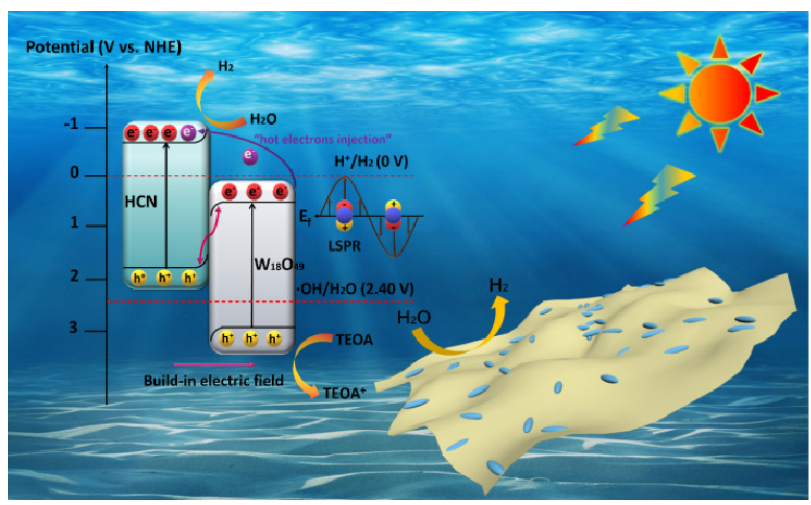

[4] L. L. Sun, Y. J. Zhou, X. Li, J. Z. Li, D. Shen, S. K. Yin, H. Q. Wang, P. W. Huo, Y. S. Yan, Chin. J. Catal., 2020, 41, 1573-1588.

[5] Y. J. Wang, Y. Li, S. W. Cao, J. G. Yu, Chin. J. Catal., 2019, 40, 867-874.

[6] Y. Guo, Y. R. Li, C. M. Wang, R. Long, Y. J. Xiong, Acta Chim. Sin., 2019, 77, 520-524.

[7] Q. Q. Liu, J. X. Huang, H.Tang, X. H. Yu, J. Shen, J. Mater. Sci. Technol., 2020, 56, 196-205.

[8] D. Q. Zeng, T. Zhou, W.-J. Ong, M. D. Wu, X. G. Duan, W. J. Xu, Y. Z. Chen, Y.-A. Zhu, D.-L. Peng, ACS Appl. Mater. Interfaces, 2019, 11, 5651-5660.

[9] Z. Li, Y. N. Ma, X. Y. Hu, E. Z. Liu, J. Fan, Chin. J. Catal., 2019, 40, 434-445.

[10] Q. Q. Liu, J. Y. Shen, X. H. Yu, X. F. Yang, W. Liu, J. Yang, H. Tang, H. Xu, H. M. Li, Y. Y. Li, J. S. Xu, Appl. Catal. B, 2019, 248, 84-94.

[11] N. Xiao, S. S. Li, S. Liu, B. R. Xu, Y. D. Li, Y. Q. Gao, L. Ge, G. W. Lu, Chin. J. Catal., 2019, 40, 352-361.

[12] X. J. Chen, R. Shi, Q. Chen, Z. J. Zhang, W. J. Jiang, Y. F. Zhu, T. R. Zhang, Nano Energy, 2019, 59, 644-650.

[13] H. Tang, R. Wang, C. X. Zhao, Z. P. Chen, X. F. Yang, D. Bukhvalov, Z. X. Lin, Q. Q. Liu, Chem. Eng. J., 2019, 374, 1064-1075.

[14] K. H. Sun, J. Shen, Q. Q. Liu, H. Tang, M. Y. Zhang, S. Zulfiqar, C. S. Lei, Chin. J. Catal., 2020, 41, 72-81.

[15] L. Y. Huang, F. Zhang, Y. P. Li, H. Wang, Q. Wang, C. B. Wang, H. Xu, H. M. Li, J. Mater. Sci., 2019, 54, 5343-5358.

[16] J. J. Peng, J. Shen, X. X. Yu, H. Tang, Zulfiqar, Q. Q. Liu, Chin. J. Catal., 2021, 42, 87-96.

[17] I. Mondal, H. Lee, H. Kim, J. Y. Park, Adv. Funct. Mater., 2020, 30, 1908239.

[18] Z. Y. Zhang, X. Y. Jiang, B. K. Liu, L. J. Guo, N. Lu, L. Wang, J. D. Huang, K. C. Liu, B. Dong, Adv. Mater., 2018, 30, 1705221.

[19] C. C. Jia, X. Zhang, K. Matras-Postolek, B. B. Huang, P. Yang, Carbon, 2018, 139, 415-426.

[20] Q. W. Liu, Y. W. We, J. W. Zhang, K. J. Chen, C. J. Huang, H. Chen, X. Q. Qiu, Appl. Surf. Sci., 2019, 490, 395-402.

[21] Q. Xie, W. M. He, S. W. Liu, C. H. Li, J. F. Zhang, P. K. Wong, Chin. J. Catal., 2020, 41, 140-153.

[22] P. F. Chen, X. Q. Dai, P. X. Xing, X. Y. Zhao, Q. L. Zhang, S. F. Ge, J. X. Si, L. H. Zhao, Y. M. He, J. Ind. Eng. Chem., 2019, 80, 74-82.

[23] R. Wang, J. Shen, W. Zhang, Q. Liu, M. Zhang, Zulfiqar, H. Tang, Ceram. Int., 2020, 46, 23-30.
[24] J. H. Luo, Z. X. Lin, Y. Zhao, S. J. Jiang, S. Q. Song, Chin. J. Catal., 2020 41, 122-130.

[25] F. He, A. Y. Meng, B. Cheng, W. K. Ho, J. G. Yu, Chin. J. Catal., 2020, 41, 9-20.

[26] J. W. Fu, Q. L. Xu, J. X. Low, C. J. Jiang, J. G. Yu, Appl. Catal. B, 2019, 243, 556-565.

[27] T. Giannakopoulou, I. Papailias, N. Todorova, N. Boukos, Y. Liu, J. G. Yu, C. Trapalis, Chem. Eng. J., 2017, 310, 571-580.

[28] F. T. Li, Y. Zhao, Q. Wang, X. J. Wang, Y. J. Hao, R. H. Liu, D. S. Zhao, J. Hazard. Mater., 2015, 283, 371-381.

[29] Y. C. Deng, L. Tang, C. Y. Feng, G. M. Zeng, Z. M. Chen, J. J. Wang, H. P. Feng, B. Peng, Y. N. Liu, Y. Y. Zhou, Appl. Catal. B, 2018, 235, 225-237.

[30] G. J. Hai, J. F. Huang, Y. N. Jie, L. Y. Cao, L. Wang, C. L. Fu, T. Xiao, M. F. Niu, L. L. Feng, J. Alloys Compd., 2020, 820, 153127.

[31] Z. Y. Zhang, J. D. Huang, Y. R. Fang, M. Y. Zhang, K. C. Liu, B. Dong, Adv. Mater., 2017, 29, 1606688.

[32] M. J. Liu, S. Wageh, A. A. Al-Ghamdi, P. F. Xia, B. Cheng, L. Y. Zhang, J. G. Yu, Chem. Commun., 2019, 55, 14023-14026.

[33] Q. Y. Chen, S. J. Li, H. Y. Xu, G. F. Wang, Y. Qu, P. F. Zhu, D. S. Wang, Chin. J. Catal., 2020, 41, 514-523.

[34] F. Xu, D. N. Zhang, Y. L. Liao, G. Wang, X. L. Shi, H. W. Zhang, Q. J. Xiang, J. Am. Ceram. Soc., 2020, 103, 849-858.

[35] M. J. Liu, P. F. Xia, L. Y. Zhang, B. Cheng, J. G. Yu, ACS Sustainable Chem. Eng., 2018, 6, 10472-10480.

[36] T. Y. Zhao, Z. P. Xing, Z. Y. Xiu, Z. Z. Li, S. L. Yang, Q. Zhu, W. Zhou, Int. J. Hydrogen Energy, 2019, 44, 1586-1596.

[37] C. Xiao, L. Zhang, H. Hao, W. Wang, ACS Sustainable Chem. Eng., 2019, 7, 7268-7276.

[38] Y. Xiao, X. Q. Tao, G. H. Qiu, Z. F. Dai, P. Gao, B. X. Li, J. Colloid Interface Sci., 2019, 550, 99-109.

[39] Y. X. Qin, X. J. Zhang, Y. Liu, W. W. Xie, J. Alloys Compd., 2016, 673, 364-371.

[40] C. Y. Feng, L. Tang, Y. C. Deng, J. J. Wang, Y. N. Liu, X. L. Ouyang, Z. M. Chen, H. R. Yang, J. F. Yu, J. J. Wang, Appl. Catal. B, 2020, 276, 119167.

[41] Y. Xiong, Z. Y. Zhu, T. C. Guo, H. Li, Q. Z. Xue, J. Hazard. Mater., 2018, 353, 290-299.

[42] N. Zhang, A. Jalil, D. X. Wu, S. M. Chen, Y. F. Liu, C. Gao, W. Ye, Z. M. Qi, H. X. Ju, C. M. Wang, X. J. Wu, L. Song, J. F. Zhu, Y. J. Xiong, J. Am. Chem. Soc., 2018, 140, 9434-9443. 
[43] H. Y. Liang, H. Zou, S. Z. Hu, New J. Chem., 2017, 41, 8920-8926.

[44] X. Liu, Y. X. Zhao, X. F. Yang, Q. Q. Liu, X. H. Yu, Y. Y. Li, H. Tang, T. R. Zhang, Appl. Catal. B, 2020, 275, 119144.

[45] H. G. Yu, W. J. Liu, X. F. Wang, F. Z. Wang, Appl. Catal. B, 2018, 225, 415-423.

[46] R. B. Wei, P. Y. Kuang, H. Cheng, Y. B. Chen, J. Y. Long, M. Y. Zhang, Z. Q. Liu, ACS Sustainable Chem. Eng., 2017, 5, 4249-4257.

[47] Y. Y. Wu, L. L. Zhang, Y. Z. Zhou, L. L. Zhang, Y. Li, Q. Q. Liu, J. Hu, J. Yang, Chin. J. Catal., 2019, 40, 691-702.

[48] Y. B. Chen, J. F. Li, P. Y. Liao, Y. S. Zeng, Z. Wang, Z. Q. Liu, Chin. Chem. Lett., 2020, 31, 1516-1519.

[49] Z. J. Sun, X. Liu, Q. D. Yue, H. X. Jia, P. W. Du, ChemCatChem, 2016, 8, 157-162.
[50] D. D. Gao, X. H. Wu, P. Wang, Y. Xu, H. G. Yu, J. G. Yu, ACS Sustain. Chem. Eng., 2019, 7, 10084-10094.

[51] J. Shen, R. Wang, Q. Q. Liu, X. F. Yang, H. Tang, J. Yang, Chin. J. Catal., 2019, 40, 380-389.

[52] R. X. Liu, X. Y. He, L. T. Niu, B. L. Lv, F. Yu, Z. Zhang, Z. W. Yang, Acta Chem. Sin., 2019, 77, 653-660.

[53] X. Q. An, K. F. Li, J. W. Tang, ChemSuschem, 2014, 7, 1086-1093.

[54] J. Xu, Q. Z. Gao, X. J. Bai, Z. P. Wang, Y. F. Zhu, Catal. Today, 2019, 332, 227-235.

[55] S. Y. Xue, C. Z. Wu, S. Y. Pu, Y. Q. Hou, T. Tong, G. Yang, Z. J. Qin, Z. M. Wang, J. M. Bao, Environ. Pollut., 2019, 250, 338-345.

[56] Z. Y. Wang, Y. Huang, L. Chen, M. J. Chen, J. J. Cao, W. K. Ho, S. C. Lee, J. Mater. Chem. A, 2018, 6, 972-981.

\section{热电子驱动氧化铇/石墨化氮化碳S-型异质结实现宽光谱光催化产氢活性

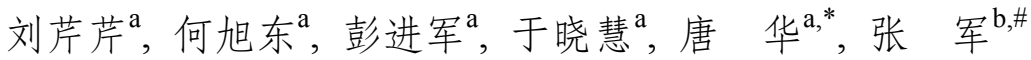 \\ ${ }^{a}$ 江苏大学材料科学与工程学院, 江苏镇江 212013 \\ $\mathrm{b}^{\mathrm{y}}$ 汉工程大学化工与制药学院, 湖北武汉 430205
}

摘要: 近年来, 等离子体材料因具有独特的局域表面等离子体共振(LSPR)效应, 可实现可见光到近红外范围内光利用, 因 此引起人们的广泛关注. 利用等离子体材料(贵金属或重掺杂半导体材料)合理构建异质结构, 可以同时拓宽光催化剂的光 谱响应范围, 抑制载流子的复合, 从而提高光催化活性. 在已报道的等离子体半导体中, $\mathrm{WO}_{3-x}$ 具有无毒、价廉以及光谱响 应宽等优异特性. 本文通过将一维等离子体 $\mathrm{W}_{18} \mathrm{O}_{49}$ 纳米线负载到 $2 \mathrm{D} \mathrm{g}-\mathrm{C}_{3} \mathrm{~N}_{4}$ 纳米片上, 构建了 $\mathrm{WO}_{3-x} / \mathrm{HCN} \mathrm{S}$ 型异质结光催 化剂. 在可见光下光催化产氢活性测试中, 纯相质子化氮化碳 $(\mathrm{HCN})$ 的产氢活性相对较低, 为 $259 \mu \mathrm{mol} \cdot \mathrm{g}^{-1} \cdot \mathrm{h}^{-1}$, 而 $\mathrm{W}_{18} \mathrm{O}_{49} / \mathrm{HCN}$ 复合材料的产氢活性显著高于 $\mathrm{HCN}$, 其中性能最优的 $\mathrm{W}_{18} \mathrm{O}_{49} / \mathrm{HCN}$ 复合材料产氢速率为 $892 \mu \mathrm{mol} \cdot \mathrm{g}^{-1} \cdot \mathrm{h}^{-1}$, 约为 $\mathrm{HCN}$ 的 3.4 倍. 在 $550 \mathrm{~nm}$ 单色光照射下, $\mathrm{W}_{18} \mathrm{O}_{49} / \mathrm{HCN}$ 复合材料的产氢速率仍有 $41.5 \mu \mathrm{mol} \cdot \mathrm{g}^{-1} \cdot \mathrm{h}^{-1}$, 纯相 $\mathrm{HCN}$ 和 $\mathrm{W}_{18} \mathrm{O}_{49}$ 均未有 $\mathrm{H}_{2}$ 生成. 在 $420,450,520 \mathrm{~nm}$ 处测得的 $\mathrm{W}_{18} \mathrm{O}_{49} / \mathrm{HCN}$ 复合材料的表观量子效率分别为 $6.21 \%, 1.28 \%$ 和 $0.14 \% . \mathrm{W}_{18} \mathrm{O}_{49}$ 纳米线起 着扩展光吸附和热电子供体的双重作用, 使 $\mathrm{WO}_{3-x} / \mathrm{g}-\mathrm{C}_{3} \mathrm{~N}_{4}$ 具有宽光谱响应的光催化分解水活性. 等离子体 $\mathrm{W}_{18} \mathrm{O}_{49}$ 纳米线可 以产生热电子, 热电子转移到 $\mathrm{HCN}$ 的导带 $(\mathrm{CB})$, 参与水还原反应, 实现宽光谱的光催化产氢活性.

利用固体紫外测试确定了 $\mathrm{W}_{18} \mathrm{O}_{49} / \mathrm{HCN}$ 复合材料能带结构, 与传统的 $\mathrm{WO}_{3}$ 催化剂相比, $\mathrm{W}_{18} \mathrm{O}_{49}$ 在 $500-1200 \mathrm{~nm}$ 处表现出 明显的尾部吸收, 这是由于 $\mathrm{W}_{18} \mathrm{O}_{49}$ 大量的氧空位引起的 $L S P R$ 效应. 而 $\mathrm{W}_{18} \mathrm{O}_{49} / \mathrm{HCN}$ 异质结具有比 $H C N$ 更长的吸收边. 通过 第一原理密度泛函理论模拟计算了 $\mathrm{W}_{18} \mathrm{O}_{49}$ 和 $\mathrm{HCN}$ 的功函数, 分别为 5.73 和 $3.95 \mathrm{eV}$. 因此, 当 $\mathrm{HCN}$ 与 $\mathrm{W}_{18} \mathrm{O}_{49}$ 结合形成紧密的 界面时, 电子会从做功函数小的 $\mathrm{HCN}$ 向做功函数大的 $\mathrm{W}_{18} \mathrm{O}_{49}$ 移动, 直至达到费米能级平衡, 形成内建电场. 此外, 由于电子 数量的减少, $\mathrm{HCN}$ 的能带边缘向上弯曲, 而由于电子的捕获, $\mathrm{W}_{18} \mathrm{O}_{49}$ 能带边缘向下弯曲, 这种向上与向下的能带弯曲是 $\mathrm{S}$ 型 结构的典型特征之一, 这也与XPS测试结果相吻合.

$\mathrm{W}_{18} \mathrm{O}_{49} / \mathrm{HCN}$ 异质结内建电场驱动 $\mathrm{WO}_{3-x}$ 中导带 $(\mathrm{CB})$ 的电子向 $\mathrm{g}-\mathrm{C}_{3} \mathrm{~N}_{4}$ 的价带 $(\mathrm{VB})$ 移动. 在该设计中, 效率低的电子和空 穴被重新组合并排出, 而具有高氧化还原能力的功能电子和空穴则被保留下来. 不仅如此, S-scheme有望同时引导光生电 子和热电子运动, 从而避免逆电荷传递, 有利于热电子的有效利用. $\mathrm{W}_{18} \mathrm{O}_{49}$ 和 $\mathrm{g}-\mathrm{C}_{3} \mathrm{~N}_{4}$ 匹配的带隙所产生的S-scheme可以导 致较强的氧化还原能力和较高的光诱导电荷迁移速率. 对 $\mathrm{HCN}$ 与 $\mathrm{W}_{18} \mathrm{O}_{49} / \mathrm{HCN}$ 光电性能的测试结果表明, $1 \mathrm{D} / 2 \mathrm{D}$ $\mathrm{W}_{18} \mathrm{O}_{49} / \mathrm{HCN}$ 异质结的构建可以充分改善光生电子-空穴对的分离和迁移, 进而表现出更好的光催化活性. 电子自旋共振结 果也证实了 $\mathrm{W}_{18} \mathrm{O}_{49} / \mathrm{HCN}$ 中 $\mathrm{S}$ 型电荷转移机制.

关键词: 石墨化氮化碳; $\mathrm{W}_{18} \mathrm{O}_{49} ; \mathrm{S}$ 型异质结; 光催化产氢; 宽光谱

收稿日期: 2020-10-23. 接受日期: 2020-12-19. 上网时间: 2021-05-05.

*通讯联系人. 电话: (0511)88780191; 电子信箱: huatang79@163.com

\#通讯联系人. 电子信箱: zj2011@whut.edu.cn

基金来源：国家自然科学基金(21975110, 21972058); 山东省泰山学者青年专家计划.

本文的电子版全文由Elsevier出版社在ScienceDirect上出版(http://www.sciencedirect.com/journal/chinese-journal-of-catalysis). 